AJS Review 44:1 (April 2020), 183

(C) Association for Jewish Studies 2020

doi:10.1017/S0364009419000941

ABSTRACT OF HEBREW ARTICLE

\title{
Suppression of Permissive Norms in the Medieval JEWISH FAMILY Shalem Yahalom
}

The article surveys the development of the approaches towards nonfertile marital life in Ashkenazic and Sephardic communities. It appears that twelfth-century Ashkenazic Halakhah eroded the duty of procreation, leading to its permissive view of unnatural relations. In that view, aspiring to actualize sexual desires is legitimate, and satisfaction within married life prevents infidelity and sin. It should be recalled that in the Middle Ages pregnancy posed an extremely high risk to a woman's life, and unnatural relations served as an effective contraceptive method. In the thirteenth century, the trend of religious extremism in the Jewish community in France and the struggle against Cathar promiscuity in the general society led to the setting of moral and legal restrictions regarding this conduct. The new norm viewed the prevention of potential life as an act of murder, so that one who wasted semen in this manner was deserving of death as if he had committed bloodshed.

Shalem Yahalom Ariel University 